\title{
Field performance of Pinus pinea and $P$. halepensis seedlings inoculated with Rhizopogon spp. and outplanted in formerly arable land
}

\author{
Javier PARLADÉa*, Jordi LUQUE ${ }^{\mathrm{a}}$, Joan PERA ${ }^{\mathrm{a}}$, Ana M. RINCÓN ${ }^{\mathrm{b}}$ \\ ${ }^{a}$ Departament de Protecció Vegetal, IRTA, Ctra. Cabrils s/n, 08348 Cabrils (Barcelona), Spain \\ b Departamento de Fisiología y Bioquímica Vegetal, CCMA-CSIC, C/Serrano 115 bis, 28006 Madrid, Spain
}

(Received 22 May 2003; accepted 28 October 2003)

\begin{abstract}
The effect of mycorrhizal inoculation on field performance of Pinus pinea and $P$. halepensis seedlings, established in formerly arable land, was evaluated for up to 43 months after outplanting. Containerized seedlings of both tree species were produced in two different substrates, peat:bark and peat:vermiculite, and inoculated with spores of either Rhizopogon luteolus or R. roseolus. One month prior to outplanting, more than $50 \%$ of $P$. pinea short roots were colonized by either inoculated fungi, whereas a maximum of $32 \%$ of $P$. halepensis short roots were colonized by $R$. roseolus. Seedlings inoculated with $R$. roseolus were generally taller than non-inoculated ones at transplantation. However, significant differences disappeared or remained small in absolute values during the monitoring period (less than $7 \mathrm{~cm}$ in the best case, 34 months after outplanting). Inoculation with $R$. roseolus increased in $20 \%$ the survival of $P$. pinea seedlings over noninoculated ones after 43 months in the field. Under the experimental conditions tested, these differences in survival were large enough to justify inoculation costs since spore inoculation with Rhizopogon species in the nursery is easy and inexpensive. Transplant Stress Indices allowed to detect overall post-transplantation stress and further recovery periods although no clear relationship between inoculation and planting check was detected.
\end{abstract}

afforestation / field performance / mycorrhizal inoculation / Pinus / Rhizopogon

Résumé - Performances de Pinus pinea et $P$. halepensis inoculés avec Rhizopogon spp. et transplantés sur un ancien terrain agricole. L'effet de l'inoculation mycorhizienne sur la croissance et la survie de Pinus pinea et $P$. halepensis établis sur un ancien terrain agricole a été évalué pendant 43 mois après la mise en place de la plantation. Les plants des deux espèces ont été produits en conteneur sur deux substrats différents : tourbe:écorce et tourbe:vermiculite, et inoculés avec des spores de Rhizopogon luteolus, ou R. roseolus. Un mois avant la plantation, tous les plants de $P$. pinea inoculés avaient plus de $50 \%$ des racines courtes colonisées par le champignon inoculé sans distinction d'espèce ou de substrat. Les plants de $P$. halepensis n'avaient au maximum que $32 \%$ des racines courtes colonisées par $R$. roseolus. Les plants inoculés avec $R$. roseolus étaient généralement les plus hauts au moment de la transplantation. Ces différences significatives sont néanmoins restées petites voire ont disparu au cours du temps (moins de $7 \mathrm{~cm}$, dans le meilleur cas, 34 mois après l'établissement de la plantation). La survie des plants de $P$. pinea inoculés avec $R$. roseolus a augmenté de $20 \%$ par rapport à celle des plants témoins après 43 mois en plantation. Dans les conditions expérimentées, les différences de survie étaient assez grandes pour justifier le coût de l'inoculation, surtout parce que l'inoculation avec des spores de champignons du genre Rhizopogon est facile à appliquer en pépinière. L'utilisation d'Index de Stress après transplantation ont permis de détecter des stress post-transplantation et des périodes de récupération, mais il n'a pas été établi de relation entre l'inoculation et le stress de transplantation.

inoculation mycorhizienne / performance en plantation / Pinus / reboisement / Rhizopogon

\section{INTRODUCTION}

Mycorrhizal inoculations with several plant-fungus combinations have been intended to improve seedling quality in forest nurseries [5, 18]. Inoculation techniques adapted to conventional nursery tasks have been reported and, in some cases, developed at a pre-commercial level $[11,15,16,19,20]$. Sub- sequent field-performance testing of inoculated versus noninoculated plants has covered many plant-fungus combinations and field situations $[3,4,8,12,17,18,31]$. Comprehensive data, however, are difficult to obtain since experimental conditions are very variable and most research is concentrated in small geographical regions and with few fungus-plant combinations [4]. Among the situations where mycorrhizal inoculation

* Corresponding author: xavier.parlade@irta.es 
seems to be effective to promote plant survival and growth after outplanting are the environmentally stressful sites $[4,8,21,32]$.

Restoration of low-productive formerly arable land has been promoted in the European Union (Regulation EEC 2080/92) by supporting afforestation and related management practices. Agricultural soils are generally altered by over-fertilization and their structure, chemical composition and microbial communities might not be suitable for the establishment of forest trees $[13,32]$. Also, the abundance of competing weeds is especially detrimental in Mediterranean conditions under short water availability $[2,30]$. Together with plant quality, the restoration of the below-ground microbial community has been shown to be important for the establishment of above-ground species in later successional stages [10]. Under this situation, it can be hypothesized that controlled mycorrhizal inoculation may be an advantage for forest plants to be established in formerly arable agricultural soils. To test this, we have established two experimental plantations with inoculated and non-inoculated seedlings in an abandoned cereal field representative of the Mediterranean area. Pinus halepensis Mill. and Pinus pinea L. were chosen for the study according to ecologic (adaptability) and economic (establishment and maintenance costs, production) criteria to fit the productive objectives considered in the Regulation 2080/92 [37]. Pinus halepensis became the most planted conifer in Spain under this framework [9]. Also, $P$. pinea plays an important ecological role in arid and semiarid zones by preventing erosion and is greatly valued for its edible nuts $[26,27]$. Fungal inoculations in the nursery were performed with two Rhizopogon species. The genus Rhizopogon is considered a good candidate for controlled mass inoculations in nurseries since it occurs both in young and old stands [25], can be easily inoculated in the nursery as spore suspension [5, $22,29]$ and there are reported effects on increasing field performance of inoculated plants $[4,31]$. In this study, we present the plant performance data monitored in the two established plots along 34 and 43 months after transplantation.

\section{MATERIALS AND METHODS}

\subsection{Seedling production and inoculation}

Seeds of $P$. pinea and $P$. halepensis from the Mediterranean region collected in years 1992 and 1993, respectively, were provided by Vilmorin ${ }^{\circledR}$ (Alicante, Spain). Seedlings were produced in $400 \mathrm{cc}$ Forestpot containers (Vivers La Fageda, Santa Pau, Girona, Spain) and filled with a 1:1 (v:v) mixture of either Floratorf peat (Floragard, Oldenburg, Germany) plus horticultural grade 2 vermiculite (Asfaltex, Barcelona, Spain) (p:v) or peat plus locally-composted pine bark 1:1 (v:v) (p:b). The seedlings were produced in a commercial shadehouse (Forestal Catalana S.A., Breda, Girona, Spain) in spring 1996 and 1997. Inoculation was performed one month after seeding by spraying a water suspension of spores of each Rhizopogon species prepared by blending dried sporocarps collected the previous autumn in the Montseny Range (Girona, Spain) under Abies spp. (Rhizopogon roseolus (Fr.:Fr.) Th. Fr.) or under Pinus sylvestris L. (Rhizopogon luteolus Fr.). Fungal identification was performed according to peridium and spore characteristics described by Smith [38]. For both fungal species, spore suspensions were adjusted to provide $10^{6}$ spores per seedling. Batches of 400 seedlings were produced for each combination of mycorrhizal fungus, tree species and potting substrate including non-inoculated control seedlings.
Table I. Production data of the seedlings established in the two experimental plots.

\begin{tabular}{|c|c|c|}
\hline \multirow{2}{*}{ Seedling data } & \multicolumn{2}{|c|}{ Experimental plots } \\
\hline & $\mathrm{P}-1$ & $\mathrm{P}-2$ \\
\hline Tree species & P. pinea & $\begin{array}{l}\text { P. pinea } \\
\text { P. halepensis }\end{array}$ \\
\hline Fungal inoculation treatments & $\begin{array}{l}R . \text { roseolus } \\
R . \text { luteolus } \\
\text { non-inoculated }\end{array}$ & $\begin{array}{l}\text { R. roseolus } \\
\text { non-inoculated }\end{array}$ \\
\hline Year of production & 1996 & 1997 \\
\hline $\begin{array}{l}\text { Container substrate } \\
\text { (proportions 1:1, v:v) }\end{array}$ & $\begin{array}{l}\text { Peat:bark } \\
\text { Peat:vermiculite }\end{array}$ & $\begin{array}{l}\text { Peat:bark } \\
\text { Peat:vermiculite }\end{array}$ \\
\hline Fertilization method & $\begin{array}{l}\text { Soluble fertilizer } \\
\text { (Peters 20-7-19) }\end{array}$ & $\begin{array}{l}\text { Osmocote Plus } \\
(16-8-12+2 \mathrm{MgO})\end{array}$ \\
\hline Transplantation time & April 1997 & March 1998 \\
\hline
\end{tabular}

The seedlings produced in 1996 were fertilized every 15 days with soluble NPK Peters Professional Conifer Grower 20-7-19 (Scott, Tarragona, Spain) plus micronutrients (Fetrilon 13 and Hortrilon, BASF, Barcelona, Spain). Each plant received at each fertilization $3.6 \mathrm{mg} \mathrm{N}$ (2.1 mg nitrate, $1.26 \mathrm{mg}$ ammonia, $0.24 \mathrm{mg}$ urea), $1.26 \mathrm{mg} \mathrm{P}$, $3.42 \mathrm{mg} \mathrm{K}, 0.35 \mathrm{mg} \mathrm{Fe}, 0.07 \mathrm{mg} \mathrm{Mg}, 0.06 \mathrm{mg} \mathrm{Mn}, 0.06 \mathrm{mg} \mathrm{Cu}$, $0.01 \mathrm{mg} \mathrm{Zn}, 0.01 \mathrm{mg} \mathrm{B}$, and $0.01 \mathrm{mg}$ Mo. The seedlings produced in 1997 were fertilized by mixing Osmocote Plus 16-8-12 + $2 \mathrm{MgO}$ (Scotts, Heerlen, The Netherlands) with the potting substrate at the rate of $2 \mathrm{~g} / \mathrm{L}$. Total amount of nutrients received per plant along the growing period was equivalent to that provided by the soluble fertilizer. Eleven months after inoculation, 20 seedlings of each treatment were assessed for mycorrhizal root colonization. Morphological identification of ectomycorrhizas was done according to the descriptions reported by Rincón et al. [34]. A homogeneous sample of the root system was taken from each seedling to determine the percentage of mycorrhizal colonization as described in Parladé et al. [29].

\subsection{Plantation establishment}

One-year-old seedlings were outplanted in spring 1997 and 1998 in two plots, named P-1 and P-2 respectively, established in an abandoned cereal field located in Palau Solità i Plegamans, Barcelona, Spain. Pinus pinea seedlings were established in plot $\mathrm{P}-1$ in a factorial design considering two factors: substrate (p:v and $\mathrm{p}: \mathrm{b}$ ) and inoculation (noninoculated, $R$. roseolus and $R$. luteolus). Pinus pinea and $P$. halepensis seedlings were outplanted in plot P-2 considering the same factors as in P-1 but with only two inoculation treatments: non-inoculated and $R$. roseolus. Planting stock data for both plantations are summarized in Table I. The planting area was a flat field located at $90 \mathrm{~m}$ altitude and with an average annual precipitation of $467 \mathrm{~mm}$. Soil analyses for both plots are showed in Table II. Soil preparation consisted of a superficial tillage done one month before outplanting. The seedlings were manually planted maintaining the plug intact in a completely randomized design considering a row of 18 seedlings as the experimental unit with 7 replicates per treatment. Final plantation framework was set to $2 \times 2 \mathrm{~m}$.

\subsection{Field monitoring and data analyses}

Seedling height was measured at transplantation and approximately once a year thereafter until February 2000 in plot P-1, and until October 2001 in plot P-2. Differences in growth rates between treatments were determined by comparing annual relative height growth 
Table II. Soil parameters for the two experimental plots.

\begin{tabular}{|c|c|c|c|}
\hline \multirow{2}{*}{ Soil parameter } & \multirow{2}{*}{ Determination method } & \multicolumn{2}{|c|}{ Experimental plots } \\
\hline & & $\mathrm{P}-1$ & $\mathrm{P}-2$ \\
\hline $\mathrm{pH}$ & Water $1: 2.5$ & 8.1 & 8.1 \\
\hline E.C. $25^{\circ} \mathrm{C}, 1: 5$ & Extract $1: 5,25^{\circ} \mathrm{C}$ & $0.12 \mathrm{dS} / \mathrm{m}$ & $0.19 \mathrm{dS} / \mathrm{m}$ \\
\hline Organic matter & Volumetric, electrochemical & $1.6 \%$ & $2.4 \%$ \\
\hline $\mathrm{N}$ & Kjeldahl & $0.10 \%$ & $0.14 \%$ \\
\hline $\mathrm{P}$ & Olsen & $20 \mathrm{ppm}$ & $27 \mathrm{ppm}$ \\
\hline K & Inductively coupled plasma & $152 \mathrm{ppm}$ & $543 \mathrm{ppm}$ \\
\hline Texture & USDA classification & Loam & Sandy clay loam \\
\hline
\end{tabular}

rates $\left[\left(h_{f}-h_{i}\right) / h_{i}\right]$, where $h_{i}$ : height at the beginning of the period considered and $h_{f}$ : height at the end of the growing period. Seedling survival was also determined every year after outplanting. For each plot and tree species, growth data were analyzed by ANOVA considering the following variables in the model: inoculated fungi, nursery substrate and their corresponding interaction. Differences between means were detected by Tukey's test $(P<0.05)$. Differences in seedling survival between the control and inoculated treatments were detected by chi-square test $(P<0.05)$. Transplant stress index (TSI) as described in South and Zwolinski [39] was estimated yearly for each treatment by determining the relationship between seedling height at the beginning of the period considered and the subsequent height growth. The slope of a linear relationship was interpreted as follows: if the slope was negative, the plants were experiencing planting check or transplant shock. This period lasts until the seedling establishes new roots and the direct effect of transplanting is gradually reduced. When the slope was not different from zero, the stock was recovering from planting check. A positive slope suggested that the stock had recovered from planting check. At this point, the seedlings adjusts fully and subsequent growth is the same as younger, non-transplanted trees of equivalent size.

\section{RESULTS}

\subsection{Seedling performance in plot $P-1$}

Pinus pinea seedlings produced in 1996 and inoculated with both Rhizopogon species showed a relatively high percentage of root colonization (over 50\%) before transplantation (Tab. III). However, non-inoculated control seedlings, especially those produced in peat:vermiculite, had a high level of other ectomycorrhizal fungi (mainly Thelephora terrestris Ehrh. ex Willd. Fr. and Rhizopogon-like mycorrhizas). Analyses of annual height data showed significant interactions $(P<0.05)$ between the inoculation and substrate factors. Pinus pinea seedlings produced in peat:bark and inoculated with $R$. roseolus were significantly higher than their controls at transplantation time. Also, the relative growth rate of inoculated seedlings during the first growing season in the field was significantly greater than that of non-inoculated ones (Fig. 1). The differences in height were still significant after 34 months in the field being $R$. roseolus-inoculated seedlings around $15 \%$ taller $(6.5 \mathrm{~cm}$ in average) than non-inoculated ones. On the other hand, $R$. roseolus-inoculated seedlings produced in peatvermiculite and all the seedlings inoculated with $R$. luteolus, irrespective of the substrate used, did not perform differently

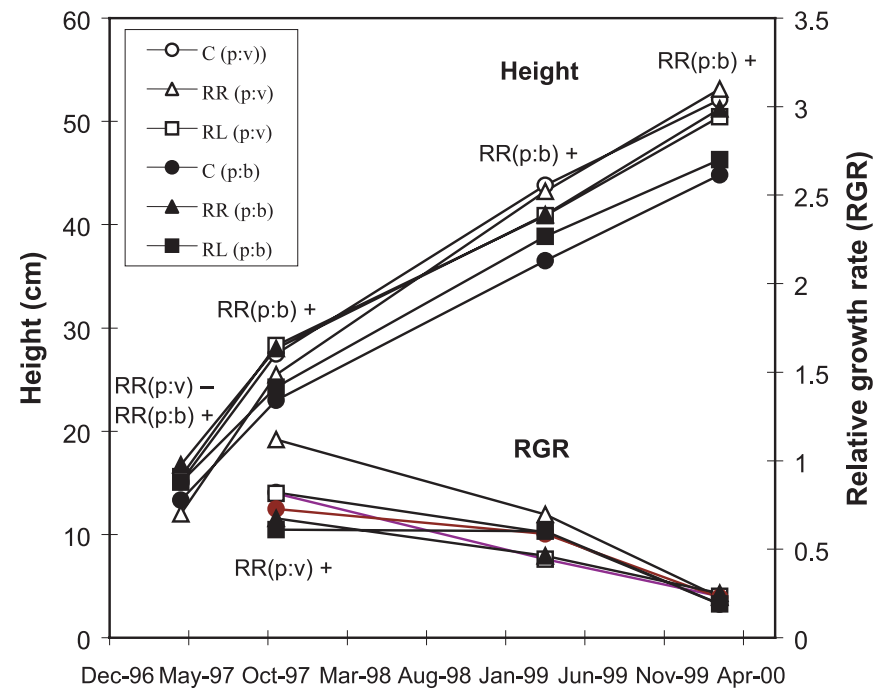

Figure 1. Evolution of height and annual relative growth rate (RGR) of Pinus pinea seedlings outplanted in the plot $\mathrm{P}-1$. For each date of assessment, the abbreviatures indicate significant differences between inoculated seedlings and their relative control by Tukey's test $(P<$ 0.05). C: control, non-inoculated seedlings; RR: Rhizopogon roseolus; RL: R. luteolus; (p:v): peat:vermiculite substrate; (p:b): peat:bark substrate; + significantly higher than control; - significantly lower than control.

than their respective non-inoculated controls (Fig. 1). Seedling survival was also significantly affected by inoculation. After 34 months in the field, the survival rate of seedlings produced in peat:bark and inoculated with $R$. roseolus was $23 \%$ higher than that of non-inoculated controls (Tab. IV). Inoculation with $R$. luteolus also improved the survival of seedlings produced in peat:bark, although this amelioration was only significant in the first measurement, 6 months after transplantation. No significant differences in survival due to inoculation were detected in seedlings produced in peat:vermiculite. In average, seedlings produced in the peat:bark substrate grew significantly less and had lower field survival than those produced in peat:vermiculite. Thus, 34 months after transplantation, non-inoculated seedlings produced in peat:vermiculite were, in average, $7 \mathrm{~cm}$ taller and had $25 \%$ more survival than seedlings produced in 
Table III. Initial colonization data of one-year-old containerized Pinus pinea and P. halepensis seedlings produced in years 1996 and 1997 to be outplanted in plots P-1 and P-2 respectively. Values are means \pm confidence intervals $(95 \%)$.

\begin{tabular}{|c|c|c|c|c|}
\hline \multirow{3}{*}{$\begin{array}{l}\text { Inoculation } \\
\text { treatment }\end{array}$} & \multirow{3}{*}{$\begin{array}{l}\text { Nursery } \\
\text { substrate }\end{array}$} & \multicolumn{3}{|c|}{ Initial colonization (\% mycorrhizas) } \\
\hline & & \multirow{2}{*}{$\begin{array}{l}1996 \\
\text { P. pinea }\end{array}$} & \multicolumn{2}{|c|}{1997} \\
\hline & & & P. pinea & P. halepensis \\
\hline Control $^{\mathrm{a}}$ & $\begin{array}{l}\text { Peat:bark } \\
\text { Peat:vermiculite }\end{array}$ & $\begin{array}{l}24 \pm 20.6 \\
59 \pm 11.4\end{array}$ & $\begin{array}{l}24 \pm 15.8 \\
17 \pm 11.9\end{array}$ & $\begin{array}{l}0 \pm 11.7 \\
2 \pm 2.4\end{array}$ \\
\hline R. roseolus & $\begin{array}{l}\text { Peat:bark } \\
\text { Peat:vermiculite }\end{array}$ & $\begin{array}{l}69 \pm 12.0 \\
83 \pm 5.2\end{array}$ & $\begin{array}{l}58 \pm 8.4 \\
64 \pm 8.5\end{array}$ & $\begin{array}{l}32 \pm 14.7 \\
24 \pm 10.2\end{array}$ \\
\hline R. luteolus & $\begin{array}{l}\text { Peat:bark } \\
\text { Peat:vermiculite }\end{array}$ & $\begin{array}{l}57 \pm 10.0 \\
88 \pm 5.0\end{array}$ & $\begin{array}{l}\text { Not produced } \\
\text { Not produced }\end{array}$ & $\begin{array}{l}\text { Not produced } \\
\text { Not produced }\end{array}$ \\
\hline
\end{tabular}

a Unidentified mycorrhizas.

Table IV. Percentage of surviving Pinus pinea seedlings at different times after transplantation in plot P-1. For each date, values followed by an asterisk are significantly different from their respective control by the chi-square test with Yates correction $(P<0.05)$.

\begin{tabular}{llccc}
\hline \multirow{2}{*}{$\begin{array}{l}\text { Nursery } \\
\text { substrate }\end{array}$} & $\begin{array}{l}\text { Inoculation } \\
\text { treatment }\end{array}$ & \multicolumn{2}{c}{ Months after transplantation } \\
\cline { 3 - 5 } & & 6 & 23 & 34 \\
\hline Peat:bark & Control & 81 & 67 & 54 \\
& R. roseolus & $94^{*}$ & $81^{*}$ & $77^{*}$ \\
& R. luteolus & $91^{*}$ & 77 & 68 \\
Peat:vermiculite & Control & 93 & 83 & 79 \\
& R. roseolus & 96 & 86 & 83 \\
& R. luteolus & 100 & 92 & 85 \\
\hline
\end{tabular}

peat:bark. Transplanting stress indices (TSI) for the seedlings established in the plot P-1 are shown in Table V. Seedlings produced in the peat:bark substrate showed values not significantly different from zero in the intervals measured up to 23 months after transplantation. Only control seedlings in the period 2334 months showed a significant positive value thus suggesting the recovery from planting check. Seedlings inoculated with $R$. roseolus and non-inoculated ones produced in peat:vermiculite showed significant negative values in the period 0-6 months thus indicating that were experiencing planting check. Positive significant values were only detected for seedlings inoculated with $R$. roseolus in the period 6-23 months after transplantation.

\subsection{Pinus pinea seedling performance in plot $\mathbf{P}-2$}

Pinus pinea seedlings inoculated with $R$. roseolus showed a high root colonization level (over $50 \%$ ) before outplanting (Tab. III). Non-inoculated controls showed less presence of other mycorrhizal fungi than seedlings produced in 1996. In average, seedlings produced in 1997 were around $20 \mathrm{~cm}$ taller than those produced in 1996. Analyses of annual height data of outplanted seedlings did not show interactions between the inoculation and substrate factors so data were analyzed together. Inoculated seedlings were significantly higher than controls at transplantation and after 20 months in the field (Fig. 2). Nevertheless, the differences were not significant thereafter. Relative

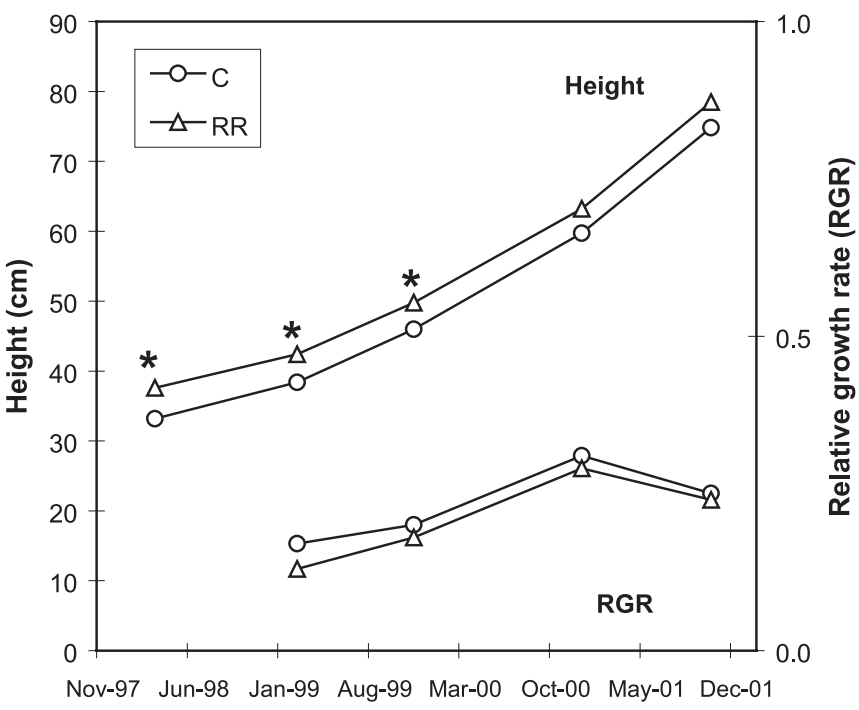

Figure 2. Evolution of height and annual relative growth rate (RGR) of Pinus pinea seedlings outplanted in the plot P-2. For each date of assessment, the asterisks next to the symbols indicate significant differences between inoculated seedlings and their control by Tukey's test $(P<0.05)$. C: control, non-inoculated seedlings; RR: Rhizopogon roseolus.

experiment and lower than those measured in plot P-1. Overall survival of $P$. pinea seedlings over time was high (Tab. VI). However, seedlings produced in peat:vermiculite and inoculated with $R$. roseolus increased $21 \%$ their survival rate compared to non-inoculated controls after 43 months in the field. Seedlings produced in peat:bark were significantly higher than those produced in peat:vermiculite in all the measurements done until 20 months from transplantation and then tended to equal (data not shown). No significant differences in survival due to the type of nursery substrate were detected. Analyses of TSI indices indicated that both inoculated and non-inoculated Pinus pinea seedlings experienced planting check up to 20 months after transplantation (Tab. VII). Positive values indicating recovery were detected in the period 33-43 months after transplantation. 
Table V. Transplant stress indices (TSI) for different growing periods from transplantation (time 0 ) in the P-1 plot. TSI values significantly different from zero are noted with asterisks: $* P<0.05$, $* * P<0.01$.

\begin{tabular}{llccc}
\hline \multirow{2}{*}{$\begin{array}{l}\text { Nursery } \\
\text { substrate }\end{array}$} & $\begin{array}{l}\text { Inoculation } \\
\text { treatment }\end{array}$ & \multicolumn{3}{c}{$\begin{array}{c}\text { Growing period from transplantation } \\
\text { (months) }\end{array}$} \\
\cline { 3 - 5 } & & $0-6$ & $6-23$ & $23-34$ \\
\hline Peat:bark & Control & -0.2 & -0.2 & $0.2^{*}$ \\
& R. roseolus & -0.2 & 0.0 & 0.1 \\
& R. luteolus & -0.0 & -0.1 & -0.0 \\
Peat:vermiculite & Control & $-0.5^{* *}$ & -0.2 & 0.1 \\
& R. roseolus & $-0.5^{*}$ & $0.4^{*}$ & 0.1 \\
& R. luteolus & -0.2 & -0.1 & -0.1 \\
\hline
\end{tabular}

\subsection{Pinus halepensis seedling performance in Plot P-2}

Pinus halepensis seedlings inoculated with $R$. roseolus showed a lower colonization level than $P$. pinea (Tab. III). Analyses of annual height data of outplanted seedlings did not show interactions between the inoculation and substrate factors so data were analyzed together. Inoculated seedlings were significantly taller than controls at transplantation and after 11 months in the field. However, differences were not significant after 20 months (Fig. 3). Relative growth rate of non-inoculated control seedlings was significantly higher than that of inoculated seedlings during the second year in the field (Fig. 3). At transplantation time, seedlings produced in peat:vermiculite were significantly higher than those produced in peat:bark although they equaled thereafter (data not shown). Survival of $P$. halepensis was not affected by inoculation (Tab. VI) or by the type of substrate. Non-inoculated P. halepensis seedlings showed significant negative TSI values in the period 0 11 months after outplanting. Positive significant values indicating recovery were obtained in the period 20-33 months after outplanting. However, in the next measured period (33-43 months) only the seedlings inoculated with $R$. roseolus showed a significant positive value (Tab. VII).

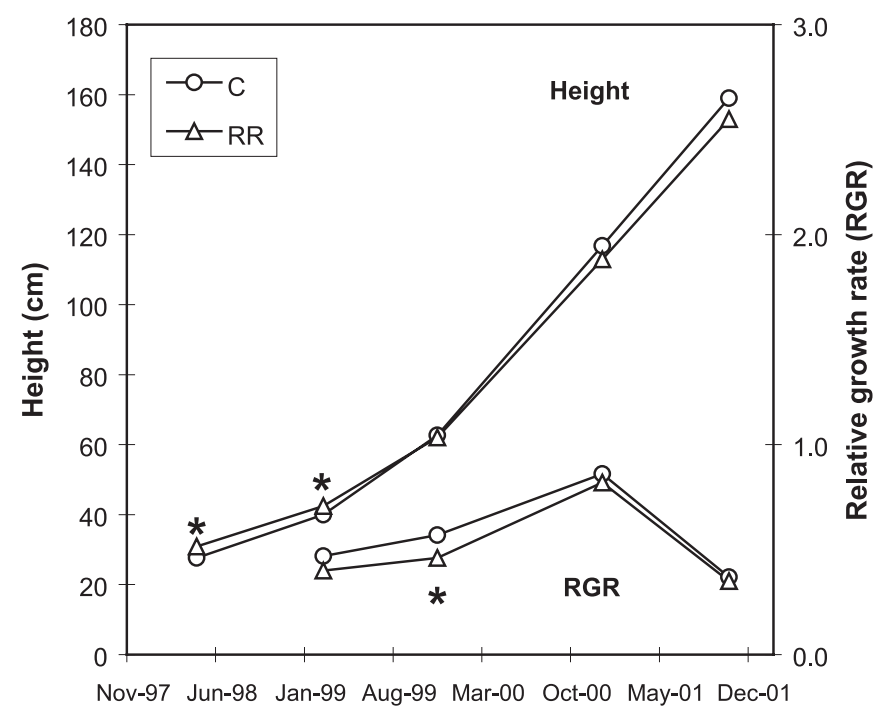

Figure 3. Evolution of height and annual relative growth rate (RGR) of Pinus halepensis seedlings outplanted in the plot P-2. For each date of assessment, the asterisks next to the symbols indicate significant differences between inoculated seedlings and their control by Tukey's test $(P<0.05)$. C: control, non-inoculated seedlings; RR: Rhizopogon roseolus.

\section{DISCUSSION}

Mycorrhizal inoculation of pines did not cause advantageous growth differences in terms of practical forestry. In the best case, significant differences in mean height were slightly over $6 \mathrm{~cm}$ in $R$. roseolus-inoculated $P$. pinea produced in peat:bark compared to non-inoculated controls, 34 months after outplanting. On the other hand, seedling growth was, in average, representative of the normal values registered in Mediterranean areas for both tree species $[2,28,36]$. Nursery inoculation with $R$. roseolus significantly increased seedling height at the end of the nursery phase except in $P$. pinea seedlings produced in peat:vermiculite in 1996. This effect is generally not found

Table VI. Percentage of surviving Pinus pinea and P. halepensis seedlings at different times after transplantation in plot P-2. For each date, values followed by an asterisk are significantly different from their respective control by the chi-square test with Yates correction $(P<0.05)$.

\begin{tabular}{|c|c|c|c|c|c|c|}
\hline \multirow{2}{*}{ Tree species } & \multirow{2}{*}{$\begin{array}{l}\text { Nursery } \\
\text { substrate }\end{array}$} & \multirow{2}{*}{$\begin{array}{l}\text { Inoculation } \\
\text { treatment }\end{array}$} & \multicolumn{4}{|c|}{ Months after transplantation } \\
\hline & & & 11 & 20 & 33 & 43 \\
\hline \multirow[t]{4}{*}{ P. pinea } & Peat:bark & Control & 98 & 96 & 91 & 86 \\
\hline & & R. roseolus & 89 & 89 & 84 & 80 \\
\hline & Peat:vermiculite & Control & 89 & 86 & 82 & 70 \\
\hline & & R. roseolus & 98 & 95 & 93 & $91 *$ \\
\hline \multirow[t]{4}{*}{ P. halepensis } & Peat:bark & Control & 97 & 92 & 88 & 86 \\
\hline & & R. roseolus & 98 & 93 & 90 & 85 \\
\hline & Peat:vermiculite & Control & 99 & 92 & 89 & 85 \\
\hline & & R. roseolus & 95 & 84 & 84 & 74 \\
\hline
\end{tabular}


Table VII. Transplant stress indices (TSI) for different growing periods from transplantation (time 0 ) in the P-2 plot. TSI values significantly different from zero are noted with asterisks: $* P<0.05$, $* * P<0.01$.

\begin{tabular}{lccccc}
\hline \multirow{2}{*}{ Tree species } & Inoculation treatment & \multicolumn{3}{c}{ Growing period from transplantation (months) } \\
\cline { 3 - 6 } & & $0-11$ & $11-20$ & $20-33$ & $33-43$ \\
\hline P. pinea & Control & $-0.1^{* *}$ & $-0.1^{* *}$ & -0.1 & $0.3^{* *}$ \\
& R. roseolus & $-0.1^{* *}$ & $-0.2^{* *}$ & -0.1 & $0.3^{* *}$ \\
P. halepensis & Control & $-0.4^{* *}$ & 0.1 & $0.4^{* *}$ & 0.0 \\
& R. roseolus & 0.0 & 0.1 & $0.5^{* *}$ & $0.2^{* *}$ \\
\hline
\end{tabular}

under container nursery conditions with fertilized artificial substrates [5, 23, 24]. Rincón et al. [35] reported that inoculation of $P$. pinea seedlings with $R$. roseolus spores did not increase seedling height under greenhouse conditions. However, Torres and Honrubia [41] found a significant growth effect of $P$. halepensis containerized seedlings 6 months after inoculation with $R$. roseolus spores. In our study, the growth effect promoted by $R$. roseolus in the nursery was maintained for some months after plantation but significant differences were not increasing with time. Differences in relative growth rate, when significant, seemed to be related with the faster growth of small plants tending to equal larger ones.

Reports of experimental plantations with inoculated $P$. pinea and $P$. halepensis seedlings are scarce in the literature. Argillier et al. [1] established $P$. pinea seedlings inoculated with Suillus collinitus (Fr.) Kuntze and found initial growth advantages due to inoculation. However, six years after outplanting, the introduced fungus was fully replaced by the native species Rhizopogon rubescens [7]. On the other hand, field outplanting of $P$. halepensis seedlings inoculated with $P$. arhizus in semiarid areas in SE Spain showed positive height increases due to inoculation two years after outplanting $[33,36]$. The differences, however, were lowered when inoculated plants were compared with those inoculated with native fungi by adding forest soil. In our study, we chose a representative arable land surrounded by natural forests where native fungal propagules are probably to occur. Although the persistence of mycorrhizas was not assessed in this study, De Miguel et al. [6] sampled $P$. pinea seedlings established in the P-2 plot one year after outplanting and found that the number of $R$. roseolus mycorrhizas was significantly higher in inoculated seedlings produced in peat:bark than in non-inoculated ones. This finding is consistent with the growth effects detected in this treatment. However, it is noteworthy that all the seedlings had $R$. roseolus mycorrhizas in some degree. Probably, a plantation framework of $2 \times 2 \mathrm{~m}$ with control and inoculated seedlings in adjacent rows caused the colonization of the former by those fungi able to extend rapidly into the soil by means of abundant extramatrical mycelium and rhizomorphs. The ability of $R$. rubescens to dominate ectomycorrhizal communities under adverse conditions was demonstrated by El Karkouri et al. [7].

Although improving outplanting performance of seedlings inoculated with Rhizopogon species has been reported [25], growth results are generally of low value for the forester in a practical sense. However, we have shown that the significant survival increase of $R$. roseolus-inoculated Pinus pinea after transplantation $(20 \%$ over control seedlings at the end of the experiment) is high enough to be taken into account, especially when analyzing the cost-benefit balance of nursery inoculations to reduce further field replanting. On the other hand, the slightly higher mortality rates detected in control seedlings in plot P-1 might be due to the high competitive pressure of weeds. Competence of weeds is considered a major problem in restoration of abandoned agricultural lands [2, 10]. It has been reported that weed competition significantly affects the number of ectomycorrhizal root tips and the distribution of ectomycorrhizal morphotypes [40]. Under this situation, mycorrhizal colonization of outplanted seedlings could improve survival by stimulating height growth in the first months after outplanting, even if growth is equaled later by non-inoculated seedlings.

The nursery conditions influenced significantly the growth of seedlings and their subsequent field performance. Transplanted one-year-old $P$. pinea seedlings fertilized with Osmocote were, in average, $20 \mathrm{~cm}$ taller than transplanted seedlings fertilized with Peters soluble fertilizer. In average, taller seedlings had higher survival rate although absolute plant height tended to equal with time due to the higher relative growth rate of small seedlings compared with that of greater ones.

The type and quality of the nursery substrate also conditioned seedling performance. Although peat:vermiculite and peat:bark are standard substrates in container-grown seedling production, the variability of peat and, especially, of composted bark is a major drawback to obtain homogeneous quality [14]. In our experiment, the $\mathrm{pH}$ of the peat:bark substrate varied from 7.7 in the batch of 1996 to 6.6 in 1997 whereas the peat:vermiculite substrate maintained $\mathrm{pH} 5$ in both cases. Relative nutrient availability in organic substrates depends greatly on $\mathrm{pH}$, being 5.5 the optimal value for conifer production [14]. According to our results, the seedlings produced in 1996 in a sub-optimal substrate (peat:bark with a high $\mathrm{pH}$ ) benefited more from inoculation with $R$. roseolus than seedlings produced in peat:vermiculite. This effect resulted in a more uniform height of $R$. roseolus-inoculated seedlings produced in either substrates compared to non-inoculated ones. The even production of seedling stock is one of the benefits reported from inoculation in nurseries by other authors $[13,32]$. The differences in substrate $\mathrm{pH}$ values were not so high in 1997 and the substrate factor did not interact with inoculation. In average, $P$. pinea seedlings produced in peat:bark in 1997 performed better than seedlings produced in peat:vermiculite and only survival of the latter was significantly improved by inoculation.

Transplant stress indices are promising indicators to estimate the intensity and duration of the planting check in both inoculated and non-inoculated seedlings. This method has been 
applied to detect differences between progenies, seedling grade, soil treatments, sites, etc. [39]. In this study, we have found that $P$. pinea established in plot $\mathrm{P}-1$ and produced in peat:vermiculite suffered planting check along the first six months after outplanting. Fully recovery was not consistent at the end of the measurements, 34 months after outplanting. Again, the presence of abundant weeds might have impeded to resume normal growth. In plot P-2, we found a similar pattern for $P$. pinea up to 34 months after outplanting but it was detected a full recovery from planting check after that. Planting check period for $P$. halepensis was restricted to the first year after outplanting and full recovery was detected in the second year. No clear relationship between inoculation and planting check period was detected. Although not assessed in this study, full recovery of seedlings could be related with the height of competing weeds. Nevertheless, more studies are needed to determine the usefulness and possibilities of this simple way of estimating plant performance after outplanting. Inoculation of seedlings for the restoration of formerly arable lands under the established experimental conditions has not resulted effective to increase plant growth in a practical sense. However, the increase in survival obtained in $P$. pinea seedlings inoculated with $R$. roseolus makes the inoculation economically feasible since the application of Rhizopogon spores in the nursery is an easy and inexpensive practice. It has been calculated that if survival was to be improved by only $5 \%$, ectomycorrhizal technology would be self-financing and even generate savings [13]. In our study, we have obtained by far this improvement due to inoculation. Also, further benefits derived from small height increases to improve competence against weeds in agricultural environments, rather than to increase plant production, need to be investigated. On the other hand, it has to be taken into account that spores are an inoculum more genetically variable than a mycelial one. Also, the collection of sporocarps may be difficult depending on the annual climatic conditions. Further research on the conservation of the ability of meiotic spores to germinate is essential for this inoculum form to be regularly applied in nursery management.

Acknowledgements: Financial support was provided by the Instituto Nacional de Investigación y Tecnología Agraria y Alimentarias (INIA), the Ministerio de Ciencia y Tecnología (MCYT), project FO96-005-C2-2, Spain, and the European Contract AIR2-CT94-1149 (MYCOMED). We wish to thank Forestal Catalana S.A. for the technical support and the Centre Educatiu 'Els Castanyers' (Departament de Justicia, Generalitat de Catalunya) for kindly providing the field site.

\section{REFERENCES}

[1] Argillier C., Falconnet G., Tillard P., Mousain D., Essais d'introduction dans un arénosol calcaire de Petite-Camargue de pins pignons (Pinus pinea L.) mycorhizés par Suillus collinitus, Rev. For. Fr. XLIX-2 (1997) 131-140.

[2] Cañellas I., Finat L., Bachiller A., Montero G., Comportamiento de planta de Pinus pinea en vivero y campo: ensayos de técnicas de cultivo de planta, fertilización y aplicación de herbicidas, Invest. Agrar. Prod. Prot. Veg. 8 (1999) 335-359.

[3] Castellano M.A., Current status of outplanting studies using ectomycorrhiza-inoculated forest trees, in: Pfleger F.L., Linderman R.G. (Eds.), Mycorrhizas and plant health, APS Press, St. Paul., MN, 1994, pp. 261-281.
[4] Castellano M.A., Outplanting performance of mycorrhizal inoculated seedlings, in: Mukergi K.G. (Ed.), Concepts in mycorrhizal research, Kluwer Academic Publishers, Dordrecht, 1996, pp. 223301.

[5] Castellano M.A., Molina R., Mycorrhizae, in: Landis T.D., Tinus R.W., McDonald S.E., Barnett J.P. (Eds.), The Container tree nursery manual, Vol. 5, Agricultural Handbook 674, Washington D.C., US Dept. Agric., For. Serv., 1989, pp. 101-167.

[6] De Miguel S., Parladé J., Pera J., Colinas C., Crecimiento y supervivencia de repoblaciones sobre tierras agrícolas con Pinus pinea L. producido sobre diferentes substratos de vivero e inoculado con Rhizopogon roseolus (Corda) Th. M. Fr., in: Junta de Castilla y León (Eds.), Libro de Actas, I Simposio del Pino Piñonero (Pinus pinea L.), Valladolid, Spain, 2000, pp. 239-251.

[7] El Karkouri K., Martín F., Mousain D., Dominance of the mycorrhizal fungus Rhizopogon rubescens in a plantation of Pinus pinea seedlings inoculated with Suillus collinitus, Ann. For. Sci. 59 (2002) 197-204.

[8] Garbaye J., Utilisation des mycorhizes en sylviculture, in: Strullu D.G. (Ed.), Les Mycorhizes des arbres et plantes cultivées, Technique et Documentation, Lavoisier, Paris, 1991, pp. 197-250.

[9] Gómez-Jover F., Jiménez F.J., Forestación de Tierras Agrícolas, Ministerio de Agricultura Pesca y Alimentación, Madrid, 1997.

[10] Hedlund K., Gormsen D., Mycorrhizal colonization of plants in setaside agricultural land, Appl. Soil Ecol. 19 (2002) 71-78.

[11] Hung L.-L.L., Trappe J.M., Ectomycorrhizal inoculation of Douglas-fir transplanted container seedlings with commercially produced inoculum, New For. 1 (1987) 141-152.

[12] Jackson R.M., Walker C., Luff S., McEvoy C., Inoculation and field testing of Sitka spruce and Douglas-fir with ectomycorrhizal fungi in the United Kingdom, Mycorrhiza 5 (1995) 165-173.

[13] Kropp B.R., Langlois C.-G., Ectomycorrhizae in reforestation, Can. J. For. Res. 20 (1990) 438-451.

[14] Landis T.D., Containers and growing media, Vol. 2, in: Nisley R.G. (Ed.), The Container tree nursery manual, Agricultural Handbook 674, Washington D.C., US Dept. Agric. For. Serv., 1990, pp. 41-85.

[15] Last F.T., Mason P.A., Wilson J., Controlled inoculation of Sitka spruce with sheating (ecto-) mycorrhizal fungi - a commercial experience in 1982, Scott. For. 38 (1984) 75-77.

[16] Le Tacon F., Jung G., Mugnier J., Michelot P., Mauperin C., Efficiency in a forest nursery of an ectomycorrhizal fungus inoculum produced in a fermentor and entrapped in polymeric gels, Can. J. Bot. 63 (1985) 1664-1668.

[17] Le Tacon F., Álvarez I.F., Bouchard D., Henrion B., Jackson R.M., Luff S., Parladé J., Pera J., Stenström E., Villeneuve N., Walker C., Variations in field response of forest trees to nursery ectomycorrhizal inoculation in Europe, in: Read D.J., Lewis D.H., Fitter A.H., Alexander I.J. (Eds.), Mycorrhizas in ecosystems, CAB International, Wallingford, 1992, pp. 119-134.

[18] Marx D.H., Ectomycorrhizal fungus inoculations: a tool for improving forestation practices, in: Mikola P. (Ed.), Tropical mycorrhiza research, Oxford University Press, New York, 1980, pp. 13-71.

[19] Marx D.H., Ruehle J.L., Kenney D.S., Cordell C.L., Riffle J.W., Molina R.J., Pawuk W.H., Navratil S., Tinus R.W., Goodwin O.C., Commercial vegetative inoculum of Pisolithus tinctorius and inoculation techniques for development of ectomycorrhizae on container-grown tree seedlings, For. Sci. 28 (1982) 373-400.

[20] Marx D.H., Cordell C.E., Kenney D.S., Mexal J.G., Artman J.D., Riffle J.W., Molina R.J., Commercial vegetative inoculum of Pisolithus tinctorius and inoculation techniques for development of ectomycorrhizae on bare-root tree seedlings, For. Sci. 30 (1984) Monograph 25.

[21] Marx D.H., Ruehle J.L., Cordell C.E., Methods for studying nursery and field response of trees to specific ectomycorrhiza, in: Norris J.R., Read D.J., Varma A.K. (Eds.), Methods in Microbiology, Academic Press, London, 1991, pp. 383-411.

[22] Massicote H.B., Molina R., Luoma D.L., Smith J.E., Biology of the ectomycorrhizal genus Rhizopogon. II. Patterns of host-fungus specificity following spore inoculation of diverse hosts grown in monoculture and dual culture, New Phytol. 126 (1994) 677-690. 
[23] Molina R., Ectomycorrhizal inoculation of containerized Douglasfir and lodgepole pine seedlings with six isolates of Pisolithus tinctorius, For. Sci. 25 (1979) 585-590.

[24] Molina R., Ectomycorrhizal inoculation of containerized western conifer seedlings, US Dept. Agric. For. Serv., Res. Note PNW-357, 1980.

[25] Molina R., Trappe J.M., Grubisha L.C., Spatafora J.W., Rhizopogon, in: Cairney J.W.G., Chambers S.M. (Eds.), Ectomycorrhizal Fungi: Key genera in profile, Springer, Berlin, 1999, pp. 129-161.

[26] Montero G., Candela J.A., Gutiérrez M., Pavón J., Ortega C., García C.G., Cañellas I., Manual de claras para repoblaciones de Pinus pinea L., EGMASA, Junta de Andalucía, Huelva, 1997.

[27] Montoya J.M., El Pino Piñonero, Ediciones Mundi-Prensa, Madrid, 1990.

[28] Oliet J.A., Planelles R., López M., Artero F., Efecto de la fertilización en vivero y del uso de protectores en plantación sobre la supervivencia y el crecimiento durante seis años de una repoblación de Pinus halepensis, Cuad. Soc. Esp. Cien. For. 10 (2000) 69-77.

[29] Parladé J., Pera J., Álvarez I.F., Inoculation of containerized Pseudotsuga menziesii and Pinus pinaster seedlings with spores of five species of ectomycorrhizal fungi, Mycorrhiza 6 (1996) 237-245.

[30] Peñuelas J.L., Ocaña L., Domínguez S., Renilla I., Experiencias sobre control de la competencia herbácea en repoblaciones de terrenos agrícolas abandonados. Resultados de tres años en campo, Cuad. Soc. Esp. Cien. For. 4 (1997) 119-126.

[31] Pera J., Álvarez I.F., Rincón A., Parladé J., Field performance in northern Spain of Douglas-fir seedlings inoculated with ectomycorrhizal fungi, Mycorrhiza 9 (1999) 77-84.

[32] Perry D.A., Molina R., Amaranthus M.P., Mycorrhizae, mycorrhizospheres, and reforestation: current knowledge and research needs, Can. J. For. Res. 17 (1987) 929-940.
[33] Querejeta J.I., Roldán A., Albadalejo J., Castillo V., The role of mycorrhizae, site preparation, and organic amendment in the afforestation of a semi-arid Mediterranean site with Pinus halepensis, For. Sci. 44 (1998) 203-211.

[34] Rincón A., Álvarez I.F., Pera J., Ectomycorrhizal fungi of Pinus pinea L. in northeastern Spain, Mycorrhiza 8 (1999) 271-276.

[35] Rincón A., Álvarez I.F., Pera J., Inoculation of containerized Pinus pinea $\mathrm{L}$. seedlings with seven ectomycorrhizal fungi, Mycorrhiza 11 (2001) 265-271

[36] Roldán A., Querejeta J.I., Albadalejo J., Castillo V., Growth response of Pinus halepensis to inoculation with Pisolithus arhizus in a terraced rangeland amended with urban refuse, Plant Soil 179 (1996) 35-43.

[37] Serrada R., Criterios para la determinación de objetivos productores en la reforestación. Elección de especie y densidad de plantación, Montes 33 (1993) 112-115.

[38] Smith A.H., A preliminary account of the North American species of Rhizopogon, Mem. N.Y. Bot. Gard. 14 (1966) 1-178.

[39] South D.B., Zwolinski J.B., Transplant stress index: a proposed method of quantifying planting check, New For. 13 (1997) 315328.

[40] Sylvia D.M., Jarstfer A.G., Distribution of mycorrhiza on competing pines and weeds in a southern pine plantation, Soil. Sci. Soc. Am. J. 61 (1997) 139-144.

[41] Torres P., Honrubia M., Inoculation of containerized Pinus halepensis (Miller) sedlings with basidiospores of Pisolithus arhizus (Pers.) Rauschert, Rhizopogon roseolus (Corda) Th. M. Fr. an Suillus collinitus (Fr.) Kuntze, Ann. Sci. For. 51 (1994) 521-528. 